\title{
Preface: “Is This a Legal Matter?"
}

In April 2018, my daughter and I were on that road trip. You know the one: one high school junior; one proud but harried mom; ten days, five or six states, twelve colleges, and 1,100 miles on the SUV.

In this version of the road trip, both the junior and the mom were musical theater nuts. The junior played the French horn; the mom taught law; this road trip was their chance to immerse themselves in the revolutionary world of Hamilton: An American Musical. They sang their way through the original cast album at least once a day. One was Eliza, one was Angelica. One was Hamilton, one was Burr. One was excited to lead her own troops. ${ }^{1}$ The other wanted to protect her from the truth that it's much harder when it's all your call. ${ }^{2}$

Around the second or third state, I was actively listening, passively driving, when it hit me. I turned to my daughter. "Take out your journal!” I said (she's that kid, the one who keeps a paper journal and sends snail mail letters and writes Hamilton quotes in beautiful calligraphy to hang on her walls). "I need you to take notes." 
And so the anthology experiment began. ${ }^{3}$ Over the next several days, my daughter and I tested a theory that Hamilton: An American Musical is a narrative not just about the Founding but about the law. And not just because Lin-Manuel Miranda has one of the most quintessentially legal names in the great name book of composers. And not just because the musical explains the writing of the Federalist Papers (although every lawyer I know is still gobsmacked about how that happened).

If you listen to the musical carefully, and if you're looking for it, the Easter egg is right there, plain enough for anyone (not just a law professor and her law-curious daughter) to hear. The story takes on any number of legal controversies. We know in the first ten minutes of the show that Aaron Burr shot Alexander Hamilton. The rest, as Rabbi Hillel famously said, is commentary. To lawyers? A legal commentary.

The road trip ended, as all good road trips do, but the theory begged to be tested. Over the next few months, I started talking to law professor friends. I posted on Facebook, “Law prof friends: Who's a huge Hamilton fan?" Among the thirty-nine almost immediate replies: "I am embarrassed to say how many times I saw it"; "Listen to the soundtrack more often than is polite to others"; and the simple, straightforward, "Who is not?" And it wasn't just law professors. At a gathering of Supreme Court lawyers, several said to me, "We quote it around the office all the time! And even in our briefs!" One federal judge told me proudly that she'd been the first to quote the musical in an opinion.

It's hardly a surprise that lawyers have responded enthusiastically to Hamilton. After all, Alexander Hamilton was a lawyer, and his passions matched those of today's lawyers in many ways. Hamilton, like lawyers across the ages, wrote like he was "running out of time" ("all day and night"), battled for clients (the U.S. Constitution, among others), tried cases (including the first murder trial in "our new nation"), fought for justice (in cabinet battles as well as his personal life), and sought to influence the formation of a new system of government in a way that would benefit the most people. He worked non-stop to write a Constitution that could survive the ages. He spoke out on the key issues of the day. And, in LinManuel Miranda's version of the story, Hamilton-like so many of the characters Shakespeare created 400 years ago-rapped soundbites that have woven themselves inextricably into lawyers' vocabulary. 
Initially, I thought of doing a symposium, or a conference, or even-why not?-a book. But symposia and conferences and books take participants. Many people, who I was told were fans, were well-known Act I Aaron Burrs to my Act I unknown Alexander Hamilton. People I didn't know, even as Facebook friends. People who, when I emailed them to introduce myself and say that I was working on a project in which I'd like to involve them, politely told me they were much too busy.

Until I said that it was about Hamilton.

Initially, just as John Jay, James Madison, and Alexander Hamilton thought there might be twenty-five Federalist Papers, evenly divided, ${ }^{4}$ I thought this book might be a slim volume of ten or twelve chapters. But when all these big-time lawyers and professors and writers enthused about explaining their own Hamilton-based legal theories, I realized that I was coordinating a much bigger project. In the end, thirty-two people I respect and admire joined me in this project.

There is simply no question that Hamilton has captured the American imagination in a way that no lesson on civics, government, the Founding of the nation, and the development of the U.S. Constitution has ever achieved. Tickets are almost impossible to acquire, more than 1.4 million cast albums had been sold by $2018,{ }^{5}$ it was the most streamed and top Billboard cast album in 2019, ${ }^{6}$ Hamilton: The Revolution has sold hundreds of thousands of copies, ${ }^{7}$ and certain phrases from the musical have become part of the American lexicon. Hamilton has infused itself into the very essence of the American experience; the musical tells the story of the beginning of that experience, and that experience is forever altered because the musical came to be. This book tells the story of how the legal landscape has been affected and changed by Hamilton: An American Musical.

I'm proud beyond measure of this volume, of this collaboration among great minds, all of whom share three important qualities: they love the law, they love Hamilton, and they see a natural connection between their legal scholarship or advocacy and the musical. Otherwise, they could not be more diverse. Some are former solicitors general of the United States; some are law school deans; some are novelists; one is a student. Some are men, some are women; some are black, some are white, some are brown; 
some consider themselves liberals, some conservatives. Some are experts in constitutional law. Some know pretty much everything there is to know about the law of copyright. Some are really into the Second Amendment, or legal history, or election law, or tort law, or immigration law. Some have spent their careers coming up with innovative ideas to help women, or people of color, or the poor.

And then there's me. I fit into some of the categories above. But can I be real a second? For just a millisecond? Let down my guard and tell the people how I feel a second? ${ }^{8}$ As I write this introduction to this book about two great passions, I look around, and I realize how lucky I am to be alive right now. ${ }^{9}$ How lucky I am to have worked on this volume with these thirty-three other lawyers - who have practiced the law, and pretty much perfected it, ${ }^{10}$ and taught it to others-alright, alright! That's what I'm talking about! ${ }^{11}$

Lisa A. Tucker 